\title{
R. Alan Culpepper and Paul N. Anderson, Eds. John and Judaism: A Contested Relationship in Context
}

(Atlanta: SBL Press, 2017), softcover, xix +442 pp.

\author{
MICHAEL G. AZAR \\ michael.azar@scranton.edu \\ University of Scranton, Scranton, PA 18510
}

In this volume, R. Alan Culpepper and Paul N. Anderson have gathered essays considering how John's "gospel and its author(s) and their community were related to Judaism" (p. xviii). Aware of the often internecine relationship between Judaism and Christianity, they write that they intend to motivate readers "toward the greater goals of knowledge and truth in the service of wholeness of life, religious devotion, and reconciliation and common purpose between Christians and Jews" (p. xix). Some essays are quite specific in their purview, while others present surveys. As such, the collection succeeds as a broad and diverse introduction both to John and to first-century Judaism.

The book is divided into four parts. In Part I ("Introduction"), Tom Thatcher ("Recent Research and Future Questions") introduces the status quaestionis in regard to John's relationship to Judaism. He also summarizes the sixteen contributions. Jan G. van der Watt (“'Is Jesus the King of Israel?': Reflections on the Jewish Nature of the Gospel of John") more specifically surveys both John's portrayal of Jesus as Israel's awaited king and his vilification of those who dissent from that association.

Part II ("John as a Source for Understanding Judaism") includes three essays, by Craig R. Koester ("The Gospel of John as a Source for First-Century Judaism"), Catrin H. Williams ("John, Judaism, and 'Searching the Scriptures"”), and Harold W. Attridge ("John, the Jews, and Philosophy"). Together, these essays consider a topic often overlooked in examinations of "John and Judaism": the ways John reveals the diversity of first-century Jewish history, hermeneutics, and hopes, especially features not preserved by later rabbis.

A major point of interaction for all of the essays of Part III ("Reappraising John's Relationship to Judaism and Jewish Christianity") is the work of J. Louis Martyn. Adele Reinhartz ("Story and History: John, Judaism, and the Historical Imagination") nicely captures the importance of Martyn's work, even among his 
detractors (Reinhartz included). Jonathan Bernier ("Jesus, 'A Modes of Religiosity") adopts Martyn's basic understanding of the

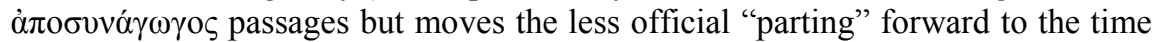
of Jesus. Craig A. Evans ("Evidence of Conflict with the Synagogue in the Johannine Writings") looks at the risk of synagogue expulsion evidenced in the other Johannine writings. Joel Marcus ("Johannine Christian and Baptist Sectarians within Late First-Century Judaism") defends Martyn's thesis through a parallel comparison of the relationship between "Johannine Christians" and the followers of the Baptist and Pharisees. Lori Baron ("The Shema in John's Gospel and Jewish Restoration Eschatology") examines John's adaptation of the biblical prophets' erstwhile reaction to exile, especially Ezekiel. The next two essaysWilliam R. G. Loader ("Tensions in Matthean and Johannine Soteriology Viewed in Their Jewish Context") and R. Alan Culpeper ("Matthew and John: Reflections of Early Christianity in Relation to Judaism") - compare John's and Matthew's varied relationships with Jewish tradition. Jörg Frey ("Toward Reconfiguring Our Views on the 'Parting of the Ways': Ephesus as a Test Case") explores John's "break" with Judaism as a geographically specific event, occurring in Ephesus but not necessarily in other centers of early Christianity.

Part IV ("Reading John as Jews and Christians") steps back from primarily historical considerations to consider the "hermeneutical implications of reading John's presentation of the Jews in a modern context" (p. 35). Reimund Bieringer ("Anti-Judaism and the Fourth Gospel Fifteen Years after the Leuven Colloquium") surveys some trends in scholarship since the 2000 colloquium in Leuven on "Anti-Judaism in the Fourth Gospel." Paul N. Anderson, in perhaps the most commendably bold essay of the collection ("Anti-Semitism and Religious Violence as Flawed Interpretations of the Gospel of John"), strives not merely to defend John against the charge of antisemitism but to establish the Gospel's positive place in Jewish-Christian relations. Ruth Sheridan ("Seed of Abraham, Slavery, and Sin: Reproducing Johannine Anti-Judaism in the Modern Commentaries on John 8:31-34") surveys modern commentaries on these verses. Noam E. Marans ("The Place of John in Christian-Jewish Relations Fifty Years after Nostra Aetate") considers the important roles played by biblical exegetes in contributing to our understanding of ancient texts in the period after Vatican II. R. Alan Culpepper ("Afterword: What Have We Learned? Where Do We Go from Here?") concludes by summarizing the contributions and briefly considering future avenues.

These essays strike a nice balance of in-depth analyses and broad summaries. In many ways - both implicitly and explicitly-the collection updates the work of reassessing John's place with regard to Judaism that started in the mid-twentieth century and culminated in the Leuven colloquium. While the collection largely succeeds at its goals, a few oversights that have sometimes hindered Johannine scholarship on "the Jews" still linger here.

Many essays in this collection (especially Anderson and van der Watt) rightly challenge the overly-broad claim that John is too "hostile" to contribute positively to our understanding of Judaism. However, the view that John did little 
for later Christian interaction with Judaism than simply pass on a "virus of hostility" deserves to be challenged as well (p. 352, quoting Culpepper). No author makes a significant attempt to understand John's impact in Christian-Jewish interaction between the first few generations of Christianity and the modern period (cf. Bieringer's observation, p. 262). Rather than investigate any aspect of the intervening period closely - particularly in the Eastern Christian world, which is overlooked entirely - the collection broadly paints the Gospel as having "fueled anti-Jewish and often anti-Semitic attitudes, hostility, and violence" (p. xviii). Such generalizations regarding Christian history too easily neglect important resources for reassessing John's, and later Christians', relationships to Judaism. Without stereotyping, and so dismissing, late-antique and medieval writers as simply Gentile appropriations of originally Jewish texts, one could appreciate more fully that "boundaries of Jewish practice were not always well defined," even after the first century (p. 75, quoting Koester). Had the authors adopted more nuanced approaches to the reception of John, this collection would succeed even more strongly at its stated goals of contributing to both "understanding" among those in the church, synagogue, and academy and "corrective action" (p. 352, quoting Culpepper) toward anti-Jewish and anti-Christian appropriations of Scripture (cf. Anderson's comments, p. 278).

For an academic study, this is an accessible volume. Footnotes and the use of unexplained technical terms are minimal, yet the authors commendably uphold a high level of scholarly sophistication. 